RICHARD TOYE

\title{
Developing Multilateralism:
}

\section{The Havana Charter and the Fight for the}

\section{International Trade Organization, I947-I948}

$\mathrm{S}$ INCE THE WorLd Trade Organization (WTO) was established in I995, it has been the subject of vocal, and sometimes violent, international protest. Much of the criticism has charged the WTO regime with placing developing countries at various kinds of unfair disadvantage. Yet complaints about international economic organizations' treatment of poor countries long predated the WTO. Such issues had affected the negotiations, in the years immediately after the Second World War, which aimed at establishing an international trade organization (ITO). Thus, although the attempt to create the ITO failed, it left a lasting legacy. Not only was the plan a precursor of the WTO, but the supposedly 'interim' general agreement on tariffs and trade (GATT), negotiated during 1947 in parallel with discussions on the proposed charter for the ITO, continued as the basis on which world trade was regulated, until superseded by the WTO. The GATT rules of I947, as subsequently amended, were nested inside the Marrakesh agreement of 1994 as part of that single agreement. Hence, the spirit of the GATT - and, to some degree, that of the ITO - lives on in the WTO.

Moreover, the failure to create the ITO - in spite of the successful negotiation of a charter for the organization at the United Nations conference on trade and employment held in Havana in 1947-8 - may perhaps be seen as a missed opportunity. The ITO might have had a wider membership than the GATT, which came to be perceived as a 'rich men's club'. ${ }^{1}$ It was not that poor countries were excluded from membership, but that the organization's activities were such that they had little motive for joining: during the I950s, it concentrated its efforts on reducing tariffs on industrial goods, an issue of limited importance to the many underdeveloped countries which had yet to industrialize. ${ }^{2}$ The ITO might have been a more attractive organization for underdeveloped countries to join, which might, in turn, have

1 See, e.g., Revisiting US Trade Policy: Decisions in Perspective, ed. A. E. Eckes, Jr. (Athens, OH, 2000), p. 20.

2 J. Toye and R. Toye, The Intellectual History of the United Nations: II: The North-South Encounter: Finance, Trade, and Development (Bloomington, 2004), introd.

The International History Review, xxv. 2: June 2003, pp. 253-504. CN ISSN 0707-5332 (C) The International History Review. All International Rights Reserved. 
promoted less autarchic/anarchic trade policies among them with additional growth benefits. This development might, in its turn, have given a further boost to the impressive post-Second World War growth in world trade that took place under the auspices of GATT. At the same time, the Havana charter's exceptions to free-trade rules, especially those made in the interests of the economic development of poorer countries, might have helped to reduce global inequalities. The possibility that the ITO might have produced a more inclusive, productive, orderly, and just world economy than that which in fact emerged lends strong interest to the reasons for its stillbirth.

The first scholar to consider why the ITO became defunct was William Diebold, a member of the United States Council on Foreign Relations, and a former member of the state department's commercial policy division. In an essay published in October I952, he sought to explain why the Truman administration, in December 1950, had quietly dropped its attempt to push the charter through congress, thus ensuring that the ITO would not come into being. Diebold argues that the administration was distracted by the cold war and not politically strong enough to steer the charter through congress. In addition, the charter itself elicited opposition not only from protectionists, but also from free-trade 'perfectionists' who felt that it marked too great a departure from liberal trade principles. This argument has been reflected in the work of subsequent scholars, and is not open to serious question. It does, however, raise the issue of why US negotiators agreed to these departures from free-trade principles, a question which must, accepting that Diebold's argument is right, form a key part of the explanation for why the attempt to create an ITO failed.

Until recently, there have been no comprehensive accounts of the conference at Havana that finalized the ITO charter (leaving aside contemporary American works aimed at persuading public, scholarly, and, in particular, congressional opinion of the charter's merits). ${ }^{1}$ Diebold was attempting 'an essay in interpretation, not an historical narrative', and therefore did not give 'a documented, play-by-play account' of the events surrounding the negotiation of the charter. ${ }^{2}$ Richard N. Gardner's classic work, first published in 1956, gave an excellent account of events both before and after the conference, but paid little attention to the conference itself. ${ }^{3}$ However, in 1995, Steve Dryden, in his history of the office of the US trade representative, provided a straightforward factual narrative of the events at Havana,

1 C. Wilcox, A Charter for World Trade (New York, 1949), pp. 47-9; W. A. Brown, The United States and the Restoration of World Trade: An Analysis and Appraisal of the ITO Charter and the General Agreement on Tariffs and Trade (Washington DC, 1950), pp. 135-60. For the text of the charter itself, see British Government White Paper, Cmd. 7375, 'United Nations Conference on Trade and Employment', April 1948 (henceforward 'Havana Charter').

2 W. Diebold, The End of the ITO (Princeton, I952), p. 3.

3 R. N. Gardner, Sterling-Dollar Diplomacy in Current Perspective: The Origins and Prospects of Our International Order (New York, I980). 
largely from the point of view of the US participants. ${ }^{1}$ Similarly, Thomas W. Zeiler concludes that the agreement reached on the charter 'was largely a product of the Cold War. That is, the United States conceded ground because of a concern that the Soviets would make political capital out of a breakdown in Cuba. ${ }^{2}$

It would be idle to deny that the imperatives of the cold war created an additional incentive for US policy-makers, who had already spent years working on the ITO charter, to complete it. As a substantial part of the world became shut off behind the iron curtain, the ITO, originally conceived of as a global institution, took on a new political purpose for the United States. Freer trade became a means of strengthening the free world economically as part of the defence against Communism, rather than, as previously, a means of eroding warlike tensions among all countries. However, to attribute the concessions made by the United States at Havana to the cold war is to beg the question of why it made those concessions in particular. As fifty-six countries attended the conference, the United States could not please everybody equally. It chose, in fact, to make concessions to the underdeveloped countries. At the same time, it refused key concessions to European countries, especially Britain, which were vital cold war allies essential to the defence of Western Europe. Clearly, the 'cold war' explanation for the outcome at Havana is in need of clarification and refinement.

Without ignoring the cold war context, this article argues that the outcome of the conference was substantially a product of the US decision to extend its concept of multilateralism so as to allow a wide range of countries to help to design the new organization, rather than hoping that they would accede, passively, to a US blueprint. As decolonization added to the numbers of independent countries available to take part in the negotiations, and as - partly in consequence - the concept of economic underdevelopment gained a new importance in international affairs, there was increased pressure for the ITO to be designed with the needs of poor countries in mind. This was apparent even before the outbreak in earnest of the cold war in early I 947. Furthermore, granting special treatment to underdeveloped countries inevitably involved sacrificing some of the interests of developed countries. The United States's willingness to do this enraged, in particular, the British, who became increasingly isolated in the face of the US-led coalition. Nevertheless, in spite of their reservations, the British signed the conference's final act - as US negotiators calculated they would because they were unwilling to be seen to jeopardize the project.

1 S. Dryden, Trade Warriors: USTR and the American Crusade for Free Trade (Oxford, 1995), pp. 9-24. See also, S. A. Aaronson, Trade and the American Dream: A Social History of Postwar Trade Policy (Lexington, KY, I996), pp. 89-9I, and The WTO as an International Organization, ed. A. O. Krueger (Chicago, I998), pp. I8I-209.

2 T. W. Zeiler, Free Trade, Free World: The Advent of GATT (Chapel Hill, 1999), p. I38. 
Hence the United States successfully exploited the multilateral format of the talks, to extend its range of alliances at the expense of Great Britain. Moreover, rather than pushing the United States towards agreement, the cold war distracted its attention from the efforts being made in Havana. The United States's comparative indifference to the ITO - not shared by the US officials present at the conference - helps to explain why the charter was ultimately dropped.

In making this argument, the article will try to correct the tendency in the literature to approach the negotiations from the US point of view. It aims to give due weight to the demands of the underdeveloped countries - which Zeiler dismisses as 'dramatics' - and to the British. ${ }^{1}$ Britain was still the world's second most powerful trading state, and the Anglo-American relationship - and the mutual suspicion in which it became mired - proved crucial to the outcome of the talks.

In July 1916, Democratic congressman Cordell Hull argued in the house of representatives that the president should call an international trade conference, to be held in Washington at the close of the war, for the purposes of establishing 'a permanent international trade congress'. (Later, in 1925, he used the term 'International Trade Organization'.) The proposed congress, he said, should consider 'all international trade methods, practices, and policies which in their effects are calculated to create destructive commercial controversies or bitter economic wars, and to formulate agreements with respect thereto, designed to eliminate and avoid the injurious results and dangerous possibilities of economic warfare, and to promote fair and friendly trade relations among all the nations of the world.'2

Prior to the Second World War, however, this idea was not practical politics. When Hull became Franklin D. Roosevelt's secretary of state in I933, he pursued freer trade bilaterally rather than multilaterally the world economic conference of 1933 was a notable failure - under the Reciprocal Trade Agreements Act (RTAA) of I934. When US planning for the post-war world started within the state department in 1939, it was predicated at first on the assumption that progress towards freer trade would be based on the extension of the existing programme. The wartime discussions nonetheless led to a seminal shift in US trade policy, towards a multilateral approach. ${ }^{3}$ The shift affected joint Anglo-

1 Zeiler, Free Trade, p. 138. For a more detailed examination of the attitude of the underdeveloped countries, see Toye and Toye, Intellectual History, ch. I.

2 C. Hull, The Memoirs of Cordell Hull: I (London, I948), pp. 8I-2. For Hull's 1925 remark, see US $\mathrm{S}$ [enate] C[ommittee on] F[inance, $\mathrm{H}$ [earings on] I[nternational] T[rade] O[rganization] (80) S82IO-A, p. 4I.

3 See J. Miller, 'The Pursuit of a Talking Shop: Political Origins of American Multilateralism, I93445', paper presented to the 25th meeting of the Eastern Economics Association, March I999; and also Global America, ed. F. Ninkovich (Chicago, 2003). 
American planning from I94I. In July I942, James Meade (a British economist and wartime official) suggested a plan for an international commercial union, designed to create a multilateral trading system, ${ }^{1}$ which underpinned the Anglo-American talks on future international economic collaboration held in Washington in the autumn of I943. As Jamie Miller notes, by the time the talks began, the British and Americans had, for differing reasons, reached the same conclusion: the world needed a trading system that involved multilateral clearing, a multilateral negotiating mechanism for reducing tariffs, and - crucially for the argument here - multilateral influence over the design and operation of the system's rules and exceptions. ${ }^{2}$ They assumed that the creation of an international trade organization, to promote freer trade on a multilateral, non-discriminatory basis and to regulate the use of devices such as trade preferences and state trading, would help them to reach their goal.

Joint Anglo-American proposals on commercial policy were agreed in December 1945 at the time of the post-war US loan to Britain. They committed Britain to enter into negotiations for the substantial reduction of tariffs and the elimination of tariff preferences, as its contribution to a 'mutually advantageous' reduction in world trade barriers. ${ }^{3}$ The proposals were subsequently elaborated in a draft ITO charter put forward by the United States, and discussed at the first session of the preparatory committee to the UN conference on trade and employment which met between 15 October and 26 November I946, and which eighteen countries attended.

One of the most important issues that emerged was 'full employment', which was really a way of expressing concern about the stability of international demand. ${ }^{4}$ Memories of the inter-war depression triggered the fear that, in a liberalized world economy, damaging trends in the United States would rapidly cause disruption elsewhere. In particular, it was widely believed that the ability of underdeveloped countries to maintain markets for their primary products hinged on US willingness to keep up its demand for them. ${ }^{5}$ But however apparently vital, no delegation proposed international measures to expand or maintain employment. The proponents of full employment were satisfied by, first, recognition of the fact that a persistent US export surplus or a sudden, sharp decline in the US demand for imports would put other

1 The Collected Papers of Fames Meade: III: International Economics, ed. S. Howson (London, I988), pp. 27-35.

2 J. Miller, 'Wartime Origins of Multilateralism' (Ph.D. dissertation, Cambridge, 2003).

3 Cmd. 6709, 'Proposals for Consideration by an International Conference on Trade and Employment', 6 Dec. 1945.

4 Report of the Canadian Delegation to the United Nations Conference on Trade and Employment at Havana, I3 July I948, D[ocuments on] C[anadian] E[xternal] R[elations], I948, xiv. 900; see also Gardner, Sterling-Dollar Diplomacy, pp. 27I-80.

5 See John M. Leddy, Oral History, I5 June I973 [Independence, MO, Truman Presidential Library], pp. 64-5. 
countries in balance-of-payments difficulties; and second, a provision giving countries in such difficulties greater freedom than initially envisaged to use quantitative import restrictions to protect their monetary reserves. ${ }^{1}$

A second important issue was the industrialization of undeveloped areas. Australia, with the support of India, China, Lebanon, Brazil, and Chile, urged that undeveloped states should be allowed to use import quotas to help to promote industrialization. ${ }^{2}$ This apparently difficult issue was resolved, however, when the US delegation introduced into the draft charter a new chapter on economic development (chapter IV, articles IO-I3). Under this chapter, members of the ITO would 'recognize that special governmental assistance may be required in order to promote the establishment or reconstruction of particular industries and that such assistance may take the form of protective measures'. The ITO itself would be responsible for judging applications from countries to be allowed to take such measures. ${ }^{3}$ The United States, then, had made significant concessions towards the point of view of underdeveloped countries even prior to the declaration of the Truman doctrine in March 1947, which marked the real start of the cold war. Multilateral influence over the design of the ITO's rules made this inevitable.

Notwithstanding Zeiler's claim that 'the London charter corrupted free trade ideals,' the US plans for the ITO remained on course. ${ }^{4}$ The second meeting of the preparatory committee was held in April 1947 in Geneva. The revisions to the draft charter were complete by August, although the simultaneous negotiations aimed at achieving mutual tariff concessions dragged on until October. India now took over from Australia the unofficial leadership of the underdeveloped countries, which continued their efforts to secure more latitude for themselves in using measures that the developed countries believed to be inconsistent with the basic principles of multilateral trade. These efforts concentrated on freedom to use protective devices such as quantitative restrictions, differential internal taxation, mixing regulations, and preferences between neighbouring states, for the purposes of economic development. ${ }^{5}$ Another issue was the treatment of private foreign capital invested in underdeveloped countries; there was a general unwillingness to give guarantees as to its security, and, in some cases, a feeling that such capital in itself was suspect, and a likely tool of foreign exploitation.

The latter issue subsequently played an important part in alienating

1 F[oreign] R[elations of the] U[nited] S[tates], 1946, i. I36I; U[nited] N[ations], Report of the First Session of the Preparatory Committee of the United Nations Conference on Trade and Employment (London, I946), p. 5. See also Gardner, Sterling-Dollar Diplomacy, pp. 280-4.

2 Wilcox to Byrnes, 27 Dec. I946, FRUS, 1946, i. I36r.

3 UN, Report of the First Session, pp. 27-8; see also, Brown, Restoration, pp. 289-9I.

4 Zeiler, Free Trade, p. 72.

5 Report of the Canadian Delegation, I3 July I948, DCER, I948, xiv. 90 I. 
US business opinion from the ITO: the Havana charter's rule that foreign investments could not be expropriated or nationalized except under 'just', 'reasonable', or 'appropriate' conditions could be interpreted as weakening the protection that US investments abroad had previously enjoyed. ${ }^{1}$ Moreover, the United States was forced to make some significant, though not fatal, concessions over non-discrimination, new regional preferences, and the use of quantitative restrictions in the interests of economic development. ${ }^{2}$ Greater latitude for new regional preferences was in line with the new US agenda for European economic integration under the Marshall Plan. The British had favoured the freedom to discriminate and to employ quantitative restrictions in the interests of solving balance-of-payments problems; but they had worked with the Americans in trying to resist pressure from the less developed countries. Alarmingly for the US negotiators, however, on 23 August, during the round of speeches that marked the completion of the draft charter, Harold Wilson, a junior British trade minister, offered a stark warning: in the coming months and years, he said, Britain would have to use methods that 'may appear to be opposed to the principles and methods of the draft charter'. ${ }^{3}$

Wilson's announcement was the result of Britain's dire economic situation, which, days earlier, had led to the suspension of the shortlived experiment of sterling convertibility. Britain's undoubted commitment to the ITO project was being progressively undermined by its increasing doubts that it could sustain economically the full obligations incumbent upon membership were it to adopt them in the near future. At the same time, British ministers were increasingly sceptical of the United States's willingness to provide the precondition for the ITO's success by substantially reducing its own trade barriers. Accordingly, the Labour government of Clement Attlee followed a twofold strategy. On the one hand, while accepting ITO principles, it asked for the most burdensome obligations to be postponed; on the other, it doggedly resisted US demands for the substantial elimination of the imperial preference system, insisting that the proposed reductions in US tariffs, offered as a quid pro quo, were insufficient.

In the short term, this strategy was remarkably successful. In late July 1947, the British had reached the conclusion that were they to accept the non-discrimination provisions of the GATT - the preliminary agreement that was to govern world trade prior to the ITO charter coming into force - that coming November as was planned, they were unlikely to be able to live up to them. They succeeded in

\footnotetext{
1 The WTO, ed. Krueger, p. I86.

2 Gardner, Sterling-Dollar Diplomacy, pp. 36I-7; UN, Report of the Second Session of the Preparatory Committee of the United Nations Conference on Trade and Employment (London, 1947). See also, Toye and Toye, Intellectual History, ch. I.

3 Speech by Wilson, preparatory committee of the UN conference on trade and employment, 6th meeting, 23 Aug. 1947 [Geneva], W[orld] T[rade] O[rganization Archives]; Gardner, Sterling-Dollar Diplomacy, p. 357.
} 
persuading the Americans to agree to a breathing space before the provisions came into force - it lasted until the end of 1948 - thus helping Britain, and other countries, to conserve dollars. (France, independently, and apparently in ignorance of the British request, made a similar approach to the United States.) And in September, they faced down US threats that Marshall aid would be withheld from Britain unless a major move was made towards the abolition of imperial preference. ${ }^{1}$ These successes had the effect of emboldening the British, during the talks at Havana, to demand further concessions. The tactic infuriated the Truman administration, and the resulting breakdown in mutual trust had significant repercussions for the final form, and thus the eventual fate, of the ITO charter.

The conference, which was held in the Cuban parliament building, the Capitolio, in the centre of Havana, opened on 2I November. In spite of the low opinion that the Truman administration had developed of key British ministers in consequence of the stand-off at Geneva, both sides presumed that they would work together. This proved difficult. In the absence of ministerial representation, the acting leader of the British delegation was a civil servant, the second secretary to the board of trade, Stephen Holmes. His influence was undermined by both poor communication with, and political interference from, ministers in London. Of these, the chancellor of the exchequer, Sir Stafford Cripps, held sway over the more cautious Wilson, now president of the board of trade. As will be seen, Cripps's long-range interventions were maladroit, and the Havana delegation's resultant changes of tack risked provoking ridicule. As the leader of the Australian delegation, Herbert Coombs, commented towards the end of the conference, countries, such as his own, which tried to support Britain, were put in an awkward situation: 'It was embarrassing to have to change one's position as the United Kingdom's changed.'2

The US delegation proved to be better managed. Its chairman was the 'tall, strikingly handsome, beautifully attired, articulate, affable, assured' Will Clayton, formerly under-secretary of state for economic affairs, ${ }^{3}$ who had retired from the state department only the previous month. The British, who doubted the effect of his visits to the conference - he was not present continuously - underrated his effective-

1 For a full discussion, see R. Toye, 'The Attlee Government, the Imperial Preference System, and the Creation of the GATT', English Historical Review, cxviii (2003). For the French, see Wilcox to Clayton, 3 Feb. 1948, FRUS, 1948, i. 843.

2 UK D[elegation in] H[avana] to F[oreign] O[ffice], I2 March I948 [London, Public Record Office], F[oreign] O[ffice Records] 371/68886.

3 J. K. Galbraith, A Life in Our Times: Memoirs (London, 1983), p. I8I. For an account of Clayton's life, see G. A. Fossedal, Our Finest Hour: Will Clayton, the Marshall Plan, and the Triumph of Democracy (Stanford, I993). 
ness behind the scenes. ${ }^{1}$ Of similar importance was Clayton's deputy, Clair Wilcox, a former professor at Swarthmore College. He could be abrasive when crossed, and was prone to lecture other delegations on their failings. ${ }^{2}$ Nonetheless, he played a key role in the completion of the charter, bringing himself close to breakdown during the conference's final frenetic weeks.

Clayton, Wilcox, and other state department officials who shared their mindset are characterized by Zeiler as 'visionary free-traders', albeit ones who, when it came to the point, swapped their principles for expediency in order to obtain agreement to the draft charter. ${ }^{3}$ Certainly, British observers frequently derived the impression that they were wild-eyed idealists, who failed to see the world as it really was. ${ }^{4}$ Moreover, many US supporters of protectionism also shared this view, albeit from a different perspective. However, Clayton and Wilcox themselves stressed that they did not believe in complete free trade, which, they stated, would be impracticable; rather, they believed in freer trade. ${ }^{5}$ They made this point, of course, partly in deference to the strengthening of protectionist sentiment at home. The Republicans had won control of congress in 1946, making it harder for the Truman administration to win approval for measures of trade liberalization. Clayton and Wilcox were therefore eager, in order to shore up domestic support for their wider programme, to obtain an exemption for export subsidies on primary commodities from the principles of the charter. ${ }^{6}$ In this respect, the US representatives proved just as willing as those of other countries to modify free-trade principles to suit their own purposes.

Therefore, the real issue at Havana was not whether the principles would be modified, but in what ways, and to what extent. And because the majority of the fifty-six countries present were, or at least classed themselves as, economically underdeveloped, the question of development became central to discussion. ${ }^{7}$ As Wilcox subsequently recorded, 'the most violent controversies at the conference and the most protracted ones were those evoked by issues raised in the name of economic development.' He also noted that the leadership of the underdeveloped countries had shifted to the Latin American states (eighteen of which were present); and believed that the views they expressed

\footnotetext{
1 Holmes to Woods, 9 Jan. I948, FO 371/68875.

2 For a brief character sketch, see Dryden, Trade Warriors, p. I6.

3 Zeiler, Free Trade, esp. pp. 58, I43.

4 See, e.g., Lancashire and Whitehall: The Diary of Raymond Streat: II: 1939-57, ed. M. Dupree (Manchester, I987), p. 4I4.

5 See US SCFHITO (80) S82I-O-A, p. 80; UK D[elegation in] G[eneva] to FO, I7 April I947, FO 37I/6229I; and 'Summary of Statement by the Honourable William L. Clayton before the House Committee on Foreign Affairs, January 20, I 948' [College Park, MD, United States National Archives], R[ecord] G[roup] 43, I[nternational] T[rade] F[iles], box I54.

6 Brown, Restoration, pp. I46-7.

7 Zeiler, Free Trade, p. I38.
} 
were 'extreme'. ${ }^{1}$ Indeed, the Argentine delegation, under the leadership of the fervent Perónist Diego Luis Molinari, does seem to have been out to wreck the conference. Cuba and Brazil, by contrast, gave general support to the Geneva draft of the charter. ${ }^{2}$ Latin American delegations supported one another, out of solidarity, even when the issue at stake was of no importance to the country giving support. ${ }^{3}$ The Canadian delegate, Dana Wilgress, claimed privately that the Latin American countries were disturbed about the implications of the Marshall Plan: 'They felt the fairy godmother of the North was deserting them in favour of Europe. ${ }^{\prime}$

Yet, the scathing attitude of the developed countries towards the claims of the underdeveloped was by no means wholly justified. The war and post-war period had been one of profound economic dislocation, even for countries that did not suffer direct war damage. In Latin America, for example, many of the industries created in wartime stood little chance of surviving in peacetime without heavy protection. ${ }^{5}$ Such developments alarmed the developing countries, which argued that the charter in its existing form was devised for the benefit of the developed countries (which would benefit from let-outs when in economic difficulties), but did not allow the underdeveloped ones the let-outs they needed to develop their own economies. ${ }^{6}$ The division of opinion at the conference was summed up effectively by the delegate of El Salvador, Ricardo Jiménez Castillo: 'The industrialized countries' concept of equilibrium was very formal, while the underdeveloped countries felt that there should be a basic criterion - unequal treatment for unequally developed countries. ${ }^{7}$ Even if the demands of some of the undeveloped countries were extreme and not always lucidly explained, and their behaviour erratic, their demand for 'unequal treatment' deserved sympathetic consideration.

The United States stood firm, however. As a consequence, by the end of the first month the conference had made little progress. The major stumbling block was the question of quantitative import restrictions (QRs). Their use was governed by article 13 of the draft charter, added in Geneva, which provided an escape from the general embargo on them for the purposes of protection, but required that its use be approved by the ITO in advance. The underdeveloped bloc rejected the rule of 'prior approval', as they wanted more-or-less unrestricted

1 Wilcox, Charter, pp. 48, 32.

2 S. R. Niblo, War, Diplomacy, and Development: The United States and Mexico, 1938-54 (Wilmington, DE, I995), p. 2 IO; Dryden, Trade Warriors, p. I7; draft tel. prepared by the US D[elegation at] H[avana], I4 Jan. I948, FRUS, I948, i. 830-I; Wilcox to Brown, 25 Nov. I947, RG 43 ITF, box I44. 3 Draft tel., USDH, I4 Jan. I948, FRUS, I948, i. 830-I.

4 Report of the Canadian delegation, I3 July I948, DCER, I948, xiv. 902.

5 UN, Economic Survey of Latin America 1948 (New York, I949), pp. I83-4. For a discussion, see Toye and Toye, Intellectual History, ch. 6.

6 Crowe, 'ITO', 29 Dec. I947, FO 37I/68873.

7 Heads of delegations: summary record of meeting, Records of Havana Conference, 24 Dec. I947, WTO, E/Conf.2/23. 
freedom to use QRs for the purposes of economic development. On 23 December, deadlock having been reached, Wilcox told the conference that, unless the other countries accepted an agreement on the lines the United States suggested, it might employ QRs itself in the future, thus injuring other countries. ${ }^{1}$ The threat, as the Latin Americans saw it, did not have the desired effect. ${ }^{2}$ By the end of the month, the US delegation were despairing of being able to draft a charter that would find widespread acceptance.

The issue of QRs also impinged on Anglo-American relations, with significant consequences for the future of the conference. On the technical question itself, the British felt that the US position was rigid and unrealistic, but also feared that weak provisions on QRs would severely damage British exports. ${ }^{3}$ The matter was further complicated by Britain's objectives on non-discrimination. On I I December, a cabinet committee (with Attlee in the chair) considered the instructions to be given to the British delegation. Should it try to secure the continued suspension of the non-discrimination obligations agreed at Geneva? And, if so, for how long? One choice was to press for all such obligations to be deferred until March 1952, when the post-war transition period, as designated by the International Monetary Fund (IMF), would end. Of the ministers present, only Wilson was cautious, lest Britain should imperil its prospects of receiving Marshall aid free of non-discrimination obligations on the lines of those imposed by the loan agreement in 1945. He thought it prudent merely to press for an extension of the breathing space until the end of 1949. His senior colleagues, including Cripps and the foreign secretary, Ernest Bevin, overrode him. ${ }^{4}$

The demand for this concession was likely to try US patience, not least because it would encourage the underdeveloped countries to demand a quid pro quo, making it more difficult for the developed countries to hold the line on the QRs/economic development issue. As one foreign office official, C. T. Crowe, noted at the end of the month, 'while the Americans are beginning to recognise that we have a good case' for a waiver until 1952, 'the arguments for it unfortunately provide the "developers" with a first class weapon in their attack on us. ${ }^{5}$ And as Wilson pointed out to his colleagues at the end of the month (when the conference seemed on the verge of breakdown), the insistence on the extended waiver would put the British in a difficult position. If they pressed for the waiver, he suggested, the underdeveloped countries would stiffen their attitude to QRs and the United States

1 Gardner, Sterling-Dollar Diplomacy, pp. 367-8. See also, Dryden, Trade Warriors, pp. 19-20. 2 Briggs to Marshall, 28 Jan. I948, FRUS, I948, i. 837.

3 Minutes, E[conomic] P[olicy] C[ommittee], 30 Dec. I947 [London, Public Record Office] CAB [inet records] I34/215 (47) I5th; Wilson, memo, 'International Trade Conference: Prior Approval for Quantitative Restrictions', 29 Dec. I947, CAB EPC (47) 37.

4 Minutes, EPC, II Dec. I947, CAB I34/215 (47) I3th.

5 Crowe, 'ITO', 29 Dec. I947, FO 371/68873. 
would blame Britain for the failure of the conference. Although breakdown was in fact averted, Britain's insistence on the waiver did, as Wilson appeared to foresee, contribute to its isolation at Havana. ${ }^{1}$

$$
* * *
$$

At the close of the year, while British ministers canvassed amongst themselves the possibility of trying to secure a prolonged adjournment to the conference, the Truman administration considered its own options. Whereas general acceptance of the Geneva draft of the charter seemed unobtainable, the United States would not accept any text with provisions of the kind likely to be acceptable to the other countries represented at Havana. Three possibilities were considered: first, 'to press for a really acceptable Charter' with the adherence of thirty or more countries representing over 75 per cent of world trade; second, to obtain general agreement at Havana on the main points of the charter, and then adjourn the conference to New York or Geneva in June to discuss the remaining issues; and third, to settle at Havana the terms for a purely consultative or 'skeleton' ITO. At a series of meetings in Washington in early January 1948, Clayton agreed with state department officials that they should choose the first option, 'staying at Havana as long as necessary' to get a strong and acceptable charter. Wilcox, who was still in Cuba, thought the decision unwise. ${ }^{2}$ What accounted for it?

Zeiler argues that the Truman administration feared that if the talks broke down, the international alliance against Communism would be subverted. ${ }^{3}$ There is some evidence to support this contention. For example, in a memorandum of 30 December which Zeiler quotes, the economic adviser in the state department's office of international trade policy, Joseph Coppock, argued: 'The Russians would be in a position to make heavy propaganda use of the Havana failure and would be in a better position to bring other countries under their economic or political influence.' Nevertheless, it would be wrong to push the argument too far. Clayton, whose influence was crucial, was not, at this stage, a notably enthusiastic cold warrior. As late as August 1947, mere weeks before the Soviet Union announced that it would not take part in the conference, he had appeared 'to have some idealistic hope that Russia would join [the] ITO and drop her autarchic and bilateral bartering trade practices'. ${ }^{4}$ Moreover, he, and the state department, had other

1 Wilson, memo, 'International Trade Conference: Prior Approval for Quantitative Restrictions', 29 Dec. I947, CAB EPC (47) 37; minutes, EPC, 30 Dec. I947, CAB I34/215 EPC (47) I5th.

2 Memo by Brown, 5 Jan. I948, FRUS, 1948, i. 829-30; memos, Wilcox to Clayton, 29 Dec. 1947, and Brown to Clayton, 29 Dec. 1947 (marked 'not sent'), USNA, RG 43, ITF, box I44; Dryden, Trade Warriors, p. $2 \mathrm{I}$.

3 Zeiler, Free Trade, p. I43.

4 Wilson, 'Note on discussion with Mr Clayton, Geneva, I7th August, 1947', I8 Aug. 1947 [London, Public Record Office], T[reasury Records] 236/24I9. 
things on their minds than the cold war. Coppock, for one, feared that the United Nations would suffer loss of prestige in the social and economic field if the conference failed. Moreover, given that the ITO project was 'the core of the post-war economic programme which developed from the Atlantic Charter and the Lend-Lease agreements', it seems unlikely that the US officials most closely associated with it would have easily abandoned it, even had there been no cold war. ${ }^{1}$ The project had an institutional momentum behind it; its proponents may have employed cold war rhetoric less from conviction than as their best hope of obtaining a hearing in Washington. They were trying to show the ITO's continuing political relevance, at a time when it was increasingly in doubt.

Not all parts of the Truman administration were equally interested in the ITO. The US delegates in Havana had problems getting their masters back home to give it the necessary attention. In a private discussion with the British in early January, 'Clayton admitted very frankly that he had found considerable difficulty in getting United States authorities at Washington to take any connected interest in the Charter, their attention being almost entirely directed to Marshall Aid. This was one of the reasons why he was, he said, most apprehensive lest [the] Charter would be crowded out unless completed very shortly.'2 Therefore, if the cold war added urgency to the US delegation's efforts to complete the charter, this was at least in part because cold war issues were making the ITO less urgent to those higher up the political ladder. The Truman administration had not decided, as a consequence of the new global political situation, to put its all into reaching agreement at Havana, even at the cost of accepting significant compromise.

Although the US delegation pressed ahead in the face of Washington's neglect, it soon lost its sense of urgency, as it became clear that congress was unlikely to consider the charter during I948, even were it to be completed in short order. At the same time, the British and US delegations had some difficulty agreeing and sticking to a 'party line' in their dealings with the underdeveloped countries. At a meeting of the 'inner group' of countries that had attended the preparatory committee in Geneva, called to see how far it would be possible to meet the claims of the underdeveloped group without impairing the charter, Wilcox sidetracked the talks by launching into a diatribe against the alleged attempt by European countries to 'whittle down all [the] nondiscrimination obligations which they had accepted at Geneva and which he said had been largely drawn up by them for their own convenience'. ${ }^{3}$ The conference remained stuck in the doldrums for the

\footnotetext{
1 Coppock to Brown, 30 Dec. I947, FRUS, 1948 , i. 825.

$2 \mathrm{UKDH}$ to FO, 8 Jan. I948, FO 37I/68874.

$3 \mathrm{UKDH}$ to FO, I3 Jan. I948, FO 37I/68875; minute on proceedings at Havana, 30 Jan. I948, FO

37I/6888I. See also minutes, mtg., USDH, 5 Feb. I948, USNA, RG 43, ITF, box I 48.
} 
greater part of January, in spite of machiavellian US attempts, undertaken self-confessedly 'with some deliberate malice', to drive those countries which had taken part in the preparatory committee towards quick solutions. ${ }^{1}$

Then things speeded up. Wilcox noted at the end of the conference that 'December and January were a Sunday-School picnic compared to February and March.'2 The successful, if frenzied, completion of the charter during this period was contingent on a key change in US strategy, which came about as follows. A meeting of the US delegation on 6 February decided on a showdown with the Latin American countries, probably on the issue of $\mathrm{QRs}$, even at the risk of precipitating an open break with them. But later that day, the political adviser to the delegation, Albert F. Nufer, wrote a memorandum counselling 'that any such action be postponed until we have explored every possibility of reaching some agreement with the Latinos on QRs without receding from our position with regard to prior approval'. This might be done, he thought, by streamlining the ITO's procedures for approving QRs, for example by setting down a time limit for decisions. Moreover, the right which countries had under article 20 of the draft charter, to use, under certain conditions, QRs on agricultural and fisheries products without prior approval, might be extended to industrial products. This, he argued, would meet the objections of the Latin Americans, who had consistently argued that, as they were primarily exporters of agricultural products and importers of industrial products, they would be damaged by article 20 in its existing form. Nufer wrote:

In the event we force a showdown, it seems at best doubtful that our views on QR will prevail and that we will not be voted down ... An open break with the Latinos ... would have far-reaching political consequences in the Western Hemisphere. Also, it would inevitably be exploited by the Soviet Union and by the Communist groups and opposition parties in the several Latin American countries, as well as in other parts of the world. ${ }^{3}$

Although not all of Nufer's suggestions were taken up - his suggestion on article 20 was left in abeyance - the drift of his advice prevailed. On II February, the US delegation agreed to leave 'the really nasty showdown' with the underdeveloped countries until a common line had been established with the countries that had been members of the preparatory committee. ${ }^{4}$ Establishing a common line with this group involved agreeing to a set of concessions that could be offered to the developing nations to take or leave; a decision that proved crucial to the success of the conference.

1 Minutes, mtg., USDH, Io Jan. I948, USNA, RG 43, ITF, box I48.

2 Wilcox to Stinebower, 2 I March I948, USNA, RG 43, ITF, box I46.

3 Minutes, mtg., USDH, 6 Feb. I948, USNA, RG 43, ITF, box I48; memo by Nufer, 6 Feb. I948, FRUS, 1948 , i. 849-50.

4 Minutes, mtg., USDH, II Feb. I948, USNA, RG 43, ITF, box I48. 
Here was the point at which cold war concerns did prove highly important in determining the actions of the US representatives at Havana. The fear of a Communist propaganda victory added to the desire to avoid a defeat and a breach with other countries from the western hemisphere, and led the US delegation to adopt a less directly confrontational position towards the developing countries. But it was not the case, as Zeiler states, that the cold war drove the United States to make sweeping concessions to all-comers, 'rich and poor alike', in order to prevent their economies being weakened, and thus to guard against Communism. ${ }^{1}$ This was not only because the US negotiators saw the kinds of freedoms to restrict trade that others were demanding as sources of weakness rather than strength, and thus unlikely to reinforce the front against Soviet expansion, but also because they could not satisfy in full the competing demands of the developed and the underdeveloped countries. In choosing to look for a compromise with the latter, the interests of the former had to some degree to be sacrificed. This brought the United States onto a collision course with Britain.

The compromise on article I3, as finally embodied in the charter, meant that the ITO would be expected to give automatic approval to QRs on commodities not covered by existing trade agreements if any of a number of conditions were met. One, which required that the industry had been started between 1939 and 1948, was intended to cover the case of uneconomic industries started during the war or immediate post-war periods. ${ }^{2}$ The British delegation, who at first vigorously opposed the US attempt to reach this compromise with the Latin American and other underdeveloped countries, found themselves 'almost alone in seeking to restrain the Americans from progressive weakening of the text of Article I3'. They received only moderate support from Canada and France. 'In our view the United States have been astonishingly feeble in their approach to this whole problem, and we have been led to the conclusion that their attitude was dictated primarily by a wish to gain credit with the Latin American countries.'3

In London, Cripps and Wilson complained to the US ambassador, Lewis W. Douglas:

The President of the Board of Trade explained that we had given way on so many things which did not directly affect ourselves but which were of advantage, e.g., to India and to Latin American countries in allowing them to build up their industries under protection, that the result would be to limit the volume of world trade instead of restricting protective practices. We ourselves, however, were to be the only exception and we doubted whether the scheme

1 Zeiler, Free Trade, p. I46.

2 Gardner, Sterling-Dollar Diplomacy, p. 368.

$3 \mathrm{UKDH}$ to FO, 20 Feb. I948 FO 371/68883; see also, UKDH to FO, I7 Feb. I948, FO 371/68882. 
which now appeared to be emerging at Havana would be in any way acceptable to us ... We had got certain advantages at Geneva in return for the concessions we had made, but we were now asked to make further concessions and at the same time to agree to all our own protection being removed. ${ }^{1}$

In other words, Britain was being asked to agree to concessions to underdeveloped countries on QRs (under article 13), while receiving, in its own view, insufficient rights to discriminate (under article 23). But the complaint was to no avail. As Wilcox reported, gleefully, to his colleagues, 'the UK is trying to pressure us at the last minute but they cannot get away with it since the US has fifty countries lined up to support the Charter, including the rest of the British Commonwealth and Europe. The UK is absolutely isolated and their position is as impossible as that of a small boy standing in front of a steam roller.' ${ }^{2}$

The United States had also made another concession - to which the British also objected - in order to help swing other countries behind the charter in the form in which it was emerging. This was the provision, under article 15 , that the ITO would be expected to give automatic approval to new regional preference agreements, created for the purposes of economic development, if they conformed to certain agreed standards concerning size, duration, and notice to and negotiation with other countries affected. ${ }^{3}$ The concession was designed to obtain the adherence of the Arab and Central American countries to the charter, and, as the intra-regional trade of these groups of countries was of no great economic significance, most industrialized countries were willing to acquiesce. ${ }^{4}$ The British felt that the arrangement discriminated against the United Kingdom, the Commonwealth, and the Crown colonies on the grounds that these countries were not geographically contiguous. The Commonwealth and Empire should have the same rights to establish new preferences as were contemplated for countries in the same region as one another. As the ITO's approval would not have been needed for the maintenance of the existing imperial preference system, and as it was unlikely that a new Commonwealth preference system would be established, it would appear that the British made the argument as a sop to imperialist sentiment at home rather than for economic reasons. This sensitivity to domestic political factors may explain why the issue became of key importance in the minds of many British ministers.

On 25 February, Cripps and Wilson, at a second meeting with Douglas, handed him an aide-mémoire, outlining their difficulties on regional blocs, QRs, and non-discrimination. ${ }^{5}$ Cripps and Douglas were able to agree that non-discrimination could probably be dealt

1 Bevin to Inverchapel, 20 Feb. 1948, FO 371/68883.

2 Minutes, mtg., USDH, I9 Feb. I948, USNA, RG 43, ITF, box I48.

3 Gardner, Sterling-Dollar Diplomacy, pp. 366-7.

4 Wilcox to Clayton, 27 Feb. I948, FRUS, I948, i. 876-7.

5 For the text of the aide-mémoire, see UKDH to FO, 25 Feb. I948, FO 37I/68883. 
with by greater clarity in the language of the charter. Even so, Cripps said 'that in its present form it would be politically impossible to present the charter to parliament'. If it were not possible to resolve the outstanding issues quickly, he added, the conference should adjourn for two or three months. Douglas advised the state department: 'The only other course which Cripps informs me his government can take is to refuse to sign the charter,' although this was something that the British would do only with extreme reluctance. ${ }^{1}$

Wilcox, who perceived this to be a threat from Cripps, was in a strong position to resist, owing to his success in working with the European - and indeed the British - delegations to bring together the outstanding issues with the underdeveloped countries into a single package. The British delegation's support for Wilcox is evidence for its difficulties in co-ordinating its work with the government. The underdeveloped group was to be told to accept the concessions - mainly relating to new preferences and QRs - in their entirety or not at all. The United States had, with increasing success, used divide-and-rule tactics against the developing countries, securing their opposition to each other's more extreme amendments. As Wilcox noted, 'the irony of this whole situation is that the undeveloped countries, which at first were expected to have an articulate and effective bloc, have no effective bloc because their interests are too divergent to keep them together even on developmental matters." Only later, in the I960s and I970s, would Third World countries learn to co-ordinate more effectively. Therefore, at this time, in contrast to later decades, they were bought off relatively cheaply. In this way, the United States could isolate the British at little expense, using the acquiescence of the underdeveloped countries as a means to 'target' the state that was the real focus of its interest.

Moreover, the fact that British officials in Havana had helped to put together the package made it easier to call the cabinet's bluff. For if the British delegation now reversed its position on orders from Cripps, it would hardly be able to sway other countries. Its standing at the conference already showed signs of diminishing. On 27 February, Wilcox advised Clayton:

If the conference is adjourned, Cripps threatens UK will not 'sign the Charter' ... You will recall that Cripps threatened to walk out on the Geneva negotiations last summer unless we would give British complete freedom to discriminate for a year. We capitulated. Subsequently he refused flatly to carry out the commitment of his government to negotiate in good faith for the elimination of preferences. We capitulated again. Now he is employing the same tactics. But the situation is radically different. Everything is out in the open. He cannot get his way in secret. He is completely isolated - from the rest of the Common-

1 Douglas to Thorp, 25 Feb. I948, FRUS, 1948 , i. 869-72, 878; FO to UKDH, 25 Feb. I948, FO 37I/68883; FO to embassy, Washington, II March I948, FO 37I/68885.

2 Minutes, mtg., USDH, 28 Feb. I948, USNA, RG 43, ITF, box I48. 
wealth, from the countries of Europe, from the undeveloped countries of the world. We do not have to give him anything. The UK will not move to adjourn the conference. It will sign the final act. ${ }^{1}$

So it proved. By 3 March, the British were willing to accept article 13 (on QRs) as it stood. They were willing to accept article I5 (new preferences) if an interpretative note were added, stating that the ITO "need not interpret the term "economic region" to require close geographical proximity if it is satisfied that a sufficient degree of economic integration exists between the countries concerned'. ${ }^{2}$ This note, which was added to the charter, would allow the Empire, or parts of it, to be designated as belonging to the same economic region; but, as not even the other Commonwealth countries were enthusiastic, it amounted to little more than a political fig-leaf.

Non-discrimination remained the stumbling-block. The British government was now worried, probably unnecessarily, that the most recent US draft of article 23 would outlaw discriminatory bilateral trade deals into which Britain had already entered. ${ }^{3}$ At the end of February, L. P. Thompson-McCausland, a member of the British delegation specializing on the issue, was recalled for consultation with ministers. ${ }^{4}$ But, in spite of his previous assurance, Cripps now tried to do more than merely seek greater clarity in the language of the charter. On 4 March, at another meeting with Douglas, he handed over a new aide-mémoire ${ }^{5}$ in which, overriding the board of trade's officials, he included a formula giving Britain greater freedom to discriminate than the existing draft envisaged. The Truman administration, which viewed the suggestion as an attempt to get round Britain's bilateral obligations to the United States under the 1945 loan agreement, rejected it out of hand. ${ }^{6}$

Nevertheless, the Truman administration was not inflexible. It offered a dual-option text, allowing GATT-signatory countries the choice of whether to accept the criteria set by the IMF, or the criterion included in the Geneva draft of the charter. By taking the Geneva option, Britain, so long as it was in balance-of-payments difficulties, would have a general but not unfettered right to discriminate, up until 1952. Thereafter, no new forms of discrimination could be introduced without the prior approval of the ITO, but existing arrangements could continue, subject to challenge by other countries. Wilson quickly agreed. However, in a further example of poor co-ordination, the British delegation in Havana professed for several days that it knew

1 Wilcox to Clayton, 27 Feb. I948, FRUS, I948, i. 878.

2 Douglas to Marshall, 3 March I948, FRUS, I948, i. 88I-2.

3 Thompson-McCausland to Helmore, II March I948, FO 37I/68886.

4 Wilcox to Clayton, 28 Feb. I948, FRUS, 1948 , i. 880.

5 For the text of the aide-mémoire, see FO to embassy, Washington, 4 March 1948, FO 371/68883.

6 Douglas to Clayton, 4 March 1948, and Clayton to Douglas, 4 March I948, FRUS, I948, i. 884-5; FO to UKDH, 4 March I948, FO 37I/68885. 
nothing of the agreement, thus holding up the conference. ${ }^{1}$ Wilcox claimed that the British, in accepting, had shot themselves in the foot. He believed that the original US draft allowed a wider range of transitional discrimination than the Geneva text, and that the decision to take the Geneva option, although it made the board of trade happy, 'gave HMG less than it had to start with'. The key difference between the Havana and the Geneva options was that the former allowed countries in balance-of-payments difficulties, throughout the remainder of the post-war transition period, to continue to operate those discriminatory restrictions that had been in place on I March I948; whereas the latter allowed discrimination within defined functional limits without setting a base date. The British preferred the Geneva option because on I March 1948 they had been bound by the nondiscrimination provisions of the 1945 loan agreement and therefore, under the Havana option, would have had less freedom to discriminate than some other countries. Wilcox's claim, which must have rested on a belief that the Geneva option would not have allowed the continuation of various restrictions which Britain had had in force in March I948, remains moot, as there is room for doubt about how the article would have been interpreted in practice had the ITO come into being. ${ }^{2}$

What is clear, however, is that the United States had not been forced into making substantial concessions all round in order to win agreement for the charter. Having secured general acceptance for select concessions to the underdeveloped group, it made some tactical compromises in order to help to persuade Britain to swallow its doubts about them. The value of what Britain had received was debatable, and, undoubtedly, left it with little credibility in Havana.

British ministers were not under the illusion that the conference had been a success. An attempt to transfer the discussion of non-discrimination from Havana to Washington having been firmly rebuffed, the question of whether or not to sign the final act of the conference was judged sufficiently important to be brought before the cabinet on I 5 March. ${ }^{3}$ Wilson maintained his pragmatic line: 'While the final draft [charter] was in some respects less acceptable to us than the Geneva draft, we should not be supported, even by Commonwealth delegations, in pressing for the further changes which we should like to see incorporated in it.' Refusal to sign, he argued, would appear inconsistent with previous actions and statements and would seriously endanger the tariff concessions to which the United States administration had agreed. Other (unidentified) ministers objected to the terms of the

1 Minutes, mtg., USDH, Io March I948, USNA, RG 43, ITF, box I48.

2 Wilcox to Douglas, 3 March I948, FRUS, 1948, i. 883; Wilcox to Hawkins, 20 March I948, USNA, RG 43, ITF, box I46; Havana charter, article 23 and annex K; Brown, Restoration, pp. I47-52, 197203.

3 Memcon., Weiss, I2 March I948, FRUS, 1948, i. 892-4; FO to embassy, Washington, I I March I948, FO 37I/68885. 
revised article relating to new preferences: 'there was a risk of serious discrimination against the British Commonwealth in this matter.' The cabinet agreed that the British delegation should continue to try to find a more acceptable form of words; if this should not prove possible, Holmes, in signing the final act, should state that Britain interpreted the article, in conjunction with the explanatory note, to mean that the ITO would treat proposals for new preferences within the Commonwealth on the same basis as other proposals covered by the article. ${ }^{1}$ Unsurprisingly, it proved impossible to get any change in the wording at this late stage. The following week, on 24 March, Britain joined with fifty-two other countries in signing the final act of the conference. Argentina and Poland did not sign, and Turkey postponed signing until July $1948 .^{2}$

In the final round of conference speeches, Holmes struck a downbeat note. He stated that neither in its general balance nor in its detailed provisions was the charter wholly satisfactory to Britain, which would look to the ITO to prevent any unfair treatment of the Commonwealth, and would need in the early years of the organization's existence to make full use of the latitude afforded by article 23 to countries with balance-of-payments problems. While the government did intend to recommend the charter to parliament in due course, its ability to do so would depend on circumstances beyond its control. Clayton, by contrast, was jubilant: 'This may well prove to be the greatest step in history toward order and justice in economic relations among the members of the world community and toward a great expansion in the production, distribution, and consumption of goods in the world. ${ }^{3}$

American jubilation and British despondency were not, of course, proof in themselves of a substantive US triumph. The Truman administration had been defeated or outmanoeuvred on some issues. It had failed to secure an amendment to the charter by which ITO members would grant most-favoured-nation treatment to the exports of the occupied areas: Germany and Japan. It was forced to abandon what proved to be a short-lived conversion to the principle of weighted voting (as opposed to one vote for each country) in the ITO. It had been persuaded by US business interests to include in the charter provisions on the security of foreign investment, but the provisions that were actually negotiated proved, from the point of view of those interests, unacceptably weak. ${ }^{4}$

\footnotetext{
1 Minutes, cabinet, I5 March I948, CAB I28/I2, CM (48) 22 nd.

2 Brown, Restoration, p. 136.

3 'Trade Negotiations Committee: The Havana Trade Conference', memo, I4 June I948 [London, Public Record Office], B[oard of] T[rade Records] 64/484 TN (48) 5; 'Statement by the Honourable William L. Clayton at final plenary session, on 23 March I948', USNA, RG 43, ITF, box I45.

4 Zeiler, Free Trade, pp. I40-2; Dennison to Carter, I3 Dec. I947, FRUS, I948, i. 816; Aaronson,
} 
Moreover, other aspects of the charter were unpalatable to the Truman administration, even if it had long since reconciled itself to them. For example, from the US point of view, agreements for the stabilization of commodity prices were fundamentally inconsistent with the other provisions of the charter. Nonetheless, on the assumption that primary producing countries would inevitably enter into them, it accepted that it was desirable to lay down 'rules of the road' and thus eliminate some of the worst characteristics of previous such agreements. ${ }^{1}$ Other provisions left the balance of advantage open to debate. For instance, article $2 \mathrm{I}$, paragraph 4 (b) appeared to mean that no country could be required to alter policies directed towards the maintenance of full employment or the promotion of economic development, even if these created balance-of-payments difficulties. This 'looked like the perfect loophole for the indefinite retention of controls' such as QRs. ${ }^{2}$ Yet the IMF would have the responsibility for determining if a country was in such difficulties, and thus determining whether or not such controls were permissible. And, because of the IMF's system of weighted voting, the United States would have the biggest say.

In accepting the charter in its final form, had the United States sacrificed its principles, as Dryden asserts? ${ }^{3}$ Is Zeiler right to claim that 'the charter was so ridden with exceptions to free trade that much of its original meaning had been eroded in a morass of discriminatory measures'; and even that 'government regulation and protectionism served as its foundation'? (One might note in passing that the GATT, which Zeiler praises for being 'flexible', was also riddled with exceptions to free-trade rules.) $)^{4}$ Or was it the case, as Diebold implies, that the less welcome provisions, from the US point of view, were 'dubious but tolerable because they were necessary parts of an acceptable compromise'? 5 To attempt to answer these questions is, of course, to revive the contemporary controversy between the charter's advocates and its 'perfectionist' opponents. Yet this is worthwhile, as it seems that Dryden and Zeiler almost uncritically accept the arguments of the 'perfectionists'.

The arguments advanced by the US delegation in defence of its own work were mostly, if not totally, convincing. A document prepared just before the end of the Havana conference noted that the United States had held the line established at London and Geneva on twenty issues; had obtained nine positively desirable changes to the charter; had defeated several attempts to distort the ITO's purpose; had made four

Trade, pp. 90-I; Diebold, End of the ITO, pp. I8-I9.

1 US SCFHITO (80) S82I-O-A, 3I March I947, p. 475.

2 Diebold, End of the ITO, p. I6.

3 Dryden, Trade Warriors, p. 23.

4 Zeiler, Free Trade, pp. I45-6, 5

5 Diebold, End of the ITO, p. 21. 
minor concessions (including designating it 'the Havana charter', a move calculated to appeal to the Latin Americans); had made three significant compromises (on QRs, new preferences, and in allowing members to appeal to the ITO from decisions by the contracting parties denying admission to the GATT); and had failed to achieve its aim of requiring members to deny most-favoured-nation treatment to non-members. This may not have been a definitive list of gains and losses, but the final comments on the charter were compelling:

Broader scope and greater detail than any previous conference or agreement on economic relations; substance of Charter, unlike UNESCO [UN Educational, Scientific and Cultural Organization], WHO [World Health Organization], etc., pertains to vital economic interests; functions of ITO, unlike those of FAO [Food and Agriculture Organization, ILO [International Labour Organization], etc., go beyond study and recommendation - commitments in Charter limit freedom of action; commitments more numerous and more farreaching than in Bretton Woods Agreements - unaccompanied by any provision of financial assistance. ${ }^{1}$

As Clayton noted, 'viewed against the record of the inter-war years, the accomplishment of the Havana Conference is truly remarkable.' ${ }^{2}$ Of course, the US negotiators' opinions cannot be taken at face value, but their positive assessment of the charter was shared by the Canadians, who together with the Benelux countries, were better disposed towards free-trade purism than the Truman administration. ${ }^{3}$

Moreover, it might well be argued that, to the extent that the United States made concessions, they were the almost inevitable result of the, surely necessary, decision to involve other countries in the design of the ITO system. It would have been difficult, if not impossible, for the Truman administration to have obtained, from its own point of view, a better result. As Wilcox noted, 'we had come out with a Charter telling us not to do things that we would in any event not do and, furthermore, we are permitted through various exceptions to do all of the things which we wish or may have to do.' ${ }^{3}$ That, however, did not prevent US opinion from taking offence, partly because the ITO lacked powerful advocates in Washington: both Clayton and Wilcox retired after the conference, the latter to write a book aimed at persuading congress of the charter's virtues. Dean Acheson, who became secretary of state in 1949, was prepared to send the charter for congressional consideration, and to speak in favour of it, but lacked Clayton's drive and conviction on the subject. ${ }^{5}$ The outbreak of the Korean war in

1 Memo, 'Outcome of United Nations Conference on Trade and Employment', i 8 March I948, USNA, RG 43, ITF, box I54.

2 Clayton to Marshall, n.d., FRUS, 1948 , i. 900.

3 Report of the Canadian delegation, I3 July I948, DCER, I948, xiv. 915.

4 'Memo. of Conversation: ITO Charter', 25 March I948 [Independence, MO, Truman Library], Clayton-Thorp office files, box I5.

5 Leddy, Oral History, p. 74. 
June I950, which meant that congressional time had to be devoted to emergency business, sealed the ITO's fate: in December, the administration announced that it would not proceed with ratification.

$* * *$

The supposedly 'interim' GATT survived in the ITO's place. Arguably, this instrument served the United States (and other industrialized powers) at least as well as, if not better than, the ITO would have done. To what degree, then, would an ITO-based regime have been more inclusive, orderly, just, and productive than the GATT-based regime that emerged in its place? Certainly, the final stage of the negotiations for the Havana charter included more developing countries than the earlier talks that produced the GATT; and this very fact is, if anything, more important than the cold war in explaining the concessions made in these countries' favour. Whether or not the ITO would have gained a wider membership than the GATT, is, of course, a question that cannot be definitively answered. As the example of the United States demonstrates, signing the final act of the conference was no guarantee that a country would ratify the charter. Therefore, it is possible that ITO membership might not, at least at first, have reached far beyond the thirty-four countries that by April 1949 had been willing to sign the GATT. ${ }^{1}$

Nevertheless, even without a wider membership than the GATT, it is conceivable that the ITO would have been more orderly in its methods for resolving trade disputes. The great strength of the GATT as a negotiating forum was the potential for ongoing revision of its rules, giving it a flexibility that the proposed ITO lacked. On the other hand, the legal force of the GATT rules was doubtful. Moreover, legal proceedings within GATT could be stymied by countries found to be in contravention of the rules. Yet even had the ITO mechanism improved the administration of formal justice, it is still likely that the industrialized powers would have found ways to bend the rules to their own advantage. As British foreign office officials noted during the Havana talks: 'The interpretation of many of the articles of the Charter will inevitably depend on the economic strength of the parties debating them. We can therefore hope, as we regain strength, to be able to get an increasingly favourable interpretation of the development and nondiscrimination articles, provided that we remain on good terms with the USA.'2

It is also possible that, even on the optimistic assumptions of wide membership, substantively just rules, and reduced scope for gerrymandering by the great powers, the ITO would not have proved to be a substantially more economically productive regime than the GATT.

1 Zeiler, Free Trade, p. I70.

2 'International Trade Organisation Charter: Minutes', 25 Feb. 1948, FO 371/68883. 
From 1955, special treatment was granted to developing countries under GATT rules, allowing them to protect particular industries and to plead balance-of-payments reasons for adding to quantitative restrictions on trade. Yet few developing countries made wise use of these provisions. ${ }^{1}$ Nevertheless, the fact that countries may not always make best use of the freedom to do intelligent things is no reason for not granting it. To this degree, the Havana charter was a forwardlooking document.

On balance, it is not clear that, on the basis of the criteria selected, the ITO would have been a better option than the GATT. This is not, however, for the reasons that contemporary US critics and later US historians have advanced. It is not the case that the United States made inordinate or unlimited concessions in Cuba. If anything - from the point of view of establishing just rules, rather than that of reaching a settlement that would be acceptable to congress - it did not make enough. At the same time, it may be noted that the balance of those concessions - made for the most part to the underdeveloped countries, rather than to Britain and Europe - reflected the increasing political significance of what would rather later become known as 'the Third World'. This term, in itself, was loaded with cold war significance, and it would be wrong to deny that the perceived need to prove the nonCommunist world's ability to reach agreement on economic issues played a part in the US decision to press ahead with the ITO in 19478. But it was not the whole story. The United States was still learning to play at multilateralism. It did so successfully in terms of securing international agreement, but only at the price of alienating its own domestic opinion. Moreover, the issues of international economic order, justice, inclusiveness, and productivity which were under discussion at Havana were much older concerns than the cold war, and they will long outlive its end.

Homerton College, Cambridge

1 M. Pangestu, 'Special and Differential Treatment in the Millennium: Special for Whom, and How Different?', World Economy, xxiii (2000), I285-302; Order and fustice in International Relations, ed. R. Foot, J. L. Gaddis, and A. Hurrell (Oxford, 2003), pp. I03-24. 